\title{
EFFICIENCY OF THE USE OF YERBA MATE SOLAR RADIATION IN INTERCROPPING OR MONOCROPPING FOR THE ACCUMULATION OF CARBON ${ }^{1}$
}

\author{
Braulio Otomar Caron ${ }^{2}$, Denise Schmidt ${ }^{2}$, Rafaelo Balbinot ${ }^{3}$, Alexandre Behling ${ }^{4}$, Elder Eloy ${ }^{5}$ and Elvis \\ Felipe Elli ${ }^{6^{*}}$
}

\footnotetext{
${ }^{1}$ Received on 29.01.2014 accepted for publication on 24.10.2016.

${ }^{2}$ Universidade Federal de Santa Maria, Departamento de Ciências Agronômicas e Ambientais, Frederico Westphalen, RS Brasil.E-mail: <otomarcaron@yahoo.com.br>and <denise@ufsm.br>.

${ }^{3}$ Universidade Federal de Santa Maria, Departamento de Engenharia Florestal, Frederico Westphalen, RS - Brasil. E-mail: <rafaelo.balbinot@gmail.com>.

${ }^{4}$ Universidade Federal deAlagoas, Departamento de Engenharia Florestal, Maceió, AL-Brasil. E-mail:<alexandre.behling@yahoo.com.br>.

${ }^{5}$ Universidade Federal de Santa Maria, Departamento de Engenharia Florestal, Frederico Westphalen, RS - Brasil. E-mail: <eloyelder@yahoo.com.br>.

${ }^{6}$ Universidade de São Paulo (ESALQ/USP), Programa de Pós Graduação em Engenharia de Sistemas Agrícolas, Piracicaba, SP - Brasil. E-mail: <elvisfelipeelli@usp.br>.

*Corresponding author.
}

\begin{abstract}
The efficiency of solar radiation conversion is a variable often used in crop growth simulation models in which the production of biomass and, consequently, carbon accumulation are related to the conversion of radiant energy into chemical compounds by plants through the process of photosynthesis. The goal of this study was to determine the efficiency of conversion of intercepted photosynthetically active radiation (PARi) into carbon accumulation in shoots of Ilex paraguariensis in intercropping (Ilex paraguariensis A. St. Hil. and Pinus elliottii Engelm) and monoculture. The conversion efficiency of PAR in accumulated carbon was calculated based on the ratio between the accumulated carbon and the PARi involved in the process. Our results demonstrate that the higher conversion efficiency $(\varepsilon b)$ of photosynthetically active solar radiation intercepted in carbon in yerba mate sprouts was obtained in the intercropping scenario.
\end{abstract}

Keywords: Ilex paraguariensis; Photosynthetically active radiation; Intercropping.

\section{EFICIÊNCIA DO USO DA RADIAÇÃO SOLAR DE ERVA-MATE EM CULTIVO CONSORCIADO E SOLTEIRO PARA O ACÚMULO DE CARBONO}

\begin{abstract}
RESUMO - A eficiência de conversão da radiação solar é uma variável frequentemente utilizada em modelos de simulação do crescimento das culturas, pois a produção de biomassa, e consequentemente, o acúmulo de carbono, estão relacionados com a eficiência de conversão da energia radiante em química pela planta, através do processo da fotossíntese. Dessa maneira, o objetivo deste trabalho foi determinar a eficiência de conversão da radiação solar fotossinteticamente ativa interceptada (RFAi) no acúmulo de carbono na parte aérea de Ilex paraguariensis, em cultivo consorciado (Ilex paraguariensis A. St. Hil. e Pinus elliottii Engelm) e solteiro. A eficiência de conversão da RFAi em carbono acumulado foi calculado a partir da relação entre o acúmulo de carbono e a RFAi envolvida. A maior eficiência de conversão (Eb) de radiação solar fotossinteticamente ativa interceptada no acúmulo de carbono na parte aérea em plantas de ervamate é obtida no sistema de cultivo consorciado.
\end{abstract}

Palavras-chave: Ilex paraguariensis; Radiação fotossinteticamente ativa; Consórcio. 


\section{INTRODUCTION}

Yerba mate (Ilex paraguariensis A. St. Hil.) belongs to the Aquifoliaceae family, and is a native species of the temperate and subtropical regions of South America. Yerba mate is present mainly in Argentina, Paraguay and Brazil (BRUNETON, 1993; ESMELINDRO et al., 2002). This species occupies an area of 76,347 hectares in Brazil, producing about 513,256 tons (t) of green leaves, which results in an average yield of $6,723 \mathrm{tha}^{-1}$ (IBGE, 2012).

The complexity of the chemical composition of yerba mate is reported by numerous studies, since it presents substances like alkaloids (caffeine, theobromine, theophylline), alcohols, fatty acids, phenols, ketones, saponins, methylxanthines, vitamins (A, B1, B, C, and E), minerals, cellulose, gums, dextrin and saccharin (BORILLE et al., 2005; BORTOLUZZI et al., 2006; KASPARY; VALDUGA, 2008). The various compounds present in the herb mate confer a high therapeutic value to the plant, being used as an anti-inflammatory, antirheumatic, stimulant and lipolytic, besides being indicated in cases of occasional asthenia and being an adjuvant in weight loss (GOSMANN, 1989; BROMATOS, 2000). According to Mazuchowski et al. (2003), Brazilian industries have favored shade-grown and/or native yerba mate, as these are softer and more accepted by their consumers. Due to these conditions, yerba mate obtained under shading conditions has generated better prices for the producer (MAZUCHOWSKI et al., 2003).

The fact is that Poletto et al. (2010) observed that the best growth and development of yerba mate occurred at higher levels of shading. However, the cultivation of yerba mate in intercropping systems is subject to the limitation of the solar radiation due to the interception of this climatic element by the plants of the superior extract (in this case the pinus), considering that when reaching the top of the population of the highest plants. A fraction will be reflected to the atmosphere, absorbed by the plant itself and another one transmitted to the interior of the intercrop (MONTEITH; MOSS , 1977).

The growth of the yerba mate depends on the balance of dry matter accumulated by photosynthesis. The photosynthetically active radiation intercepted by a crop that is converted into phytomass reveals the efficiency of the use of radiation by the species (MONTEITH; MOSS, 1977). This knowledge can be applied to several research topics, such as analysis of plant growth, prediction of growth and production potential. According to Balbino et al. (2011), intercropping has been a great alternative to reducing greenhouse gas emissions, such as carbon dioxide $\left(\mathrm{CO}_{2}\right)$. In the same way, recent studies deal with carbon sequestration in native forests (CUNHA et al., 2009; RIBEIRO et al., 2010), in order to evaluate their potential for reducing carbon emissions.

In this sense, the determination of estimates that simulate biomass production and carbon accumulation is an important tool, both for the planning of the forest activities of yerba mate and for the environmental interest by several entities in the sense of carbon sequestration. In addition, the reduction of $\mathrm{CO}_{2}$ from the atmosphere is a priority both under the United Nations Framework Convention on Climate Change and the Kyoto Protocol (UNFCCC, 1997). Thus, in addition to the use of the leaves and branches of Ilex paraguariensis to give rise to the product "yerba mate", there is a new line of research that identifies how the photosynthetically active solar radiation is intercepted by the yerba mate, and what is the resulting amount of accumulated carbon.

The objective of this work was to determine the conversion efficiency of the intercepted photosynthetically active solar radiation (PARi) in the accumulation of carbon in the shoot of Ilex paraguariensis, in intercropping (Ilex paraguariensis A. St. Hil. and Pinus elliottii Engelm) and in monoculture (monocropping).

\section{MATERIALAND METHODS}

The experiment was developed in the geographic coordinates $27^{\circ} 23^{\prime} 26^{\prime \prime} \mathrm{S}, 53^{\circ} 25^{\prime} 43^{\prime \prime} \mathrm{W}$ at $461 \mathrm{~m}$ altitude, in the municipality of Frederico Westphalen- RS. According to Köppen's climatic classification, the predominant climate in the study area is Cfa (average air temperature of the three cooler months comprised between -3 to $18^{\circ} \mathrm{C}$, with the occurrence of precipitation in all months of the year and average air temperature in the hottest month greater or equal to $22^{\circ} \mathrm{C}$ ). Frederico Westphalen is about $30 \mathrm{~km}$ away from Iraí. According to Maluf (2000), Iraí, a municipality considered as a reference for climate classification data, presents a subhumid subtemperate climate, with an annual average temperature of $18.8^{\circ} \mathrm{C}$ and an average temperature of the coldest month of $13.3^{\circ} \mathrm{C}$. 
The experiment was carried out with two systems of yerba mate cultivation: intercropping with pine (Pinus elliottii Engel) and monocropping (cultivated in full sun). In the intercrop, the pine plants were 34 years old, with a height average of $25 \mathrm{~m}$ and a circumference at breast height $(\mathrm{CBH})$ with an average of $1.58 \mathrm{~m}$, with spacing of $8 \times 8 \mathrm{~m}$. The yerba mate plants were distributed in a spacing of $4 \times 4 \mathrm{~m}$. In the monocrop, the spacing was $3.10 \times 3.10 \mathrm{~m}$. In both systems, the herbs were the same age, 22 years old.

In the intercrop, the yerba mate plants had an average height of $2.49 \mathrm{~m}$ and an average $\mathrm{CBH}$ of 21 $\mathrm{cm}$, while in the mono it presented $2.65 \mathrm{~m}$ and $26 \mathrm{~cm}$, respectively. In order to compare the two systems, the plants in the mono system were managed with a single trunk, as verified in the intercrop.

The determination of the biomass of leaves, branches and total (leaves + branches) of three yerba mate plants were carried out in each cultivation system by season of the year, totaling 24 plants evaluated during the course of the study. In December 2006 the yerba plants were harvested, and this moment was considered the starting point of the evaluations. From this, the biomass collections started on the following dates: June 21, 2007 (beginning of winter), September 21, 2007 (early spring), December 21, 2007 (early summer), March 2008 (early fall) and the last assessment was held on June 21, 2008 (early winter). In this way, accumulated dry matter was obtained during the studied period.

The evaluations were carried out concomitantly in the two cropping systems. All the biomass of branches and leaves collected was dried in an oven with air circulation at $60^{\circ} \mathrm{C}$ until reaching constant weight, in order to determine the dry matter.

The carbon content of the species can be obtained by multiplying them by the carbon content of the species, equivalent to 0.444 per unit of biomass (WEBER et al., 2006). Therefore:

$$
\mathrm{CA}=\mathrm{DPP} * 0.444
$$

Where: $\mathrm{CA}=$ carbon accumulation, g. $\mathrm{m}^{-2}$; $\mathrm{DPP}=$ dry phytomass production, g. $\mathrm{m}^{-2}$.

According to Monteith and Moss (1977), dry phytomass production can be represented by the equation:

$$
\mathrm{DPP}=\varepsilon b * \mathrm{PARi}
$$

Where: DPP $=$ dry phytomass production, $\mathrm{g} \cdot \mathrm{m}^{-2}$; $\varepsilon b=$ efficiency of PARi conversion into dried phytomass produced, $\mathrm{g} \mathrm{MJ}^{-1}$; PARi $=$ Photosynthetically active solar radiation intercepted, $\mathrm{MJ} \mathrm{m}^{-2}$.

However, the determination of åb as a function of the accumulation of carbon and of the PARi involved can be obtained by replacing the DPP with the CA, expressed as follows:

$$
\mathrm{CA}=\varepsilon b * \mathrm{PARi}
$$

Where: $\mathrm{CA}=$ carbono accumulation, $\mathrm{g} \cdot \mathrm{m}^{-2} ; \varepsilon b=$ efficiency of PARi conversion into dried phytomass produced, $\mathrm{g} \mathrm{MJ}^{-1}$; PARi = photosynthetically active solar radiation intercepted, $\mathrm{MJ} \mathrm{m}^{-2}$.

Thus, the values can be adjusted to models in which the trend line passes through the origin, generating only the angular coefficient $(\varepsilon b)$ that corresponded to the conversion efficiency value of PARi in accumulated carbon. The photosynthetically active radiation (VARLET-GRANCHER et al., 1989) can be obtained by the equation:

$$
\text { PARi }=0.95 *(\text { PARinc }) *\left(1-\mathrm{e}\left(-\mathrm{k}^{*} \mathrm{LAI}\right)\right)
$$

Where: PARi $=$ photosynthetically active solar radiation intercepted, $\mathrm{MJ} \mathrm{m}^{-2} ; \mathrm{K}=$ constant that depends on the optimal properties of the leaves and the geometry of the vegetal canopy, $(0,8)$; LAI $=$ leaf area index, dimensionless; PARinc $=$ incidental photosynthetically active radiation, $\mathrm{MJ} \mathrm{m}^{-2}$.

The leaf area index (dimensionless) was determined from the total leaf area of each plant and the area of soil used by it (which corresponded to the spacing in meters of the crop), based on the equation:

$$
\mathrm{LAI}=\mathrm{LA} / \mathrm{SL}
$$

Where: $\mathrm{LAI}=$ leaf area index (dimensionless); LA $=$ total plant leaf area, $\mathrm{m}^{2} ; \mathrm{SL}=$ area used by the plant, $\mathrm{m}^{2}$, being $64 \mathrm{~m}^{2}(8 \times 8 \mathrm{~m})$ for the intercrop system and $9.61 \mathrm{~m}^{2}(3.1 \times 3.1 \mathrm{~m})$ for the monocrop system.

The leaf area was estimated using the "disc method" (BENINCASA, 1988). The method consisted in the removal of leaf discs of known area $\left(2.5446 \mathrm{~cm}^{2}\right.$, using a template) of the leaf limb of all the leaves that were

Revista Árvore, Viçosa-MG, v.40, n.6, p.983-990, 2016

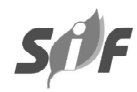


longer than five centimeters, avoiding the sampling of the central vein as recommended by Gomide et al. (1977). The number of discs varied according to the number of leaves of each plant, collecting at least one disk per sheet. Then, the leaf discs were placed in oven and circulation and air renewal at $60^{\circ} \mathrm{C}$ to obtain the dry matter. From this, the leaf area of each plant was calculated by the equation:

$$
\mathrm{LA}=(\text { number of discs*DA*DML)/DMD }
$$

Where: $\mathrm{LA}=$ leaf area, $\mathrm{m}^{2} ; \mathrm{DA}=$ disk area, $\mathrm{m}^{2}$; $\mathrm{DML}=$ dry matter of leaves, $\mathrm{g} ; \mathrm{DMD}=$ dry matter of discs, g.

The estimated photosynthetically active radiation accumulated was based on Monteith e Moss (1977) and Varlet-Grancher et al. (1989).

The values of incidental global solar radiation $(\mathrm{Rg})$ in the monocrop system were obtained from the INMET (National Meteorological Institute) Climatological Station linked to the Laboratory of Agroclimatology. The station is located about $150 \mathrm{~m}$ from the study site at coordinates $27.3956^{\circ} \mathrm{S}$ and $53.4294^{\circ} \mathrm{W}$. In order to know the percentage of incidental global radiation (Rge) that arrived in the yerba mate plants in the intercrop system, a pyranometer (LI200X, Li Cor) connected to Datalogger was used, and data were recorded every hour. The appliance was installed at level, in its own support built above the canopies. In this way, the incidental solar radiation above the canopy of the herbs was estimated according to equation 5 :

$$
\text { Rge }=0.15 * \mathrm{Rg}
$$

Where: $\mathrm{Rge}=$ incidental solar radiation, $\mathrm{MJ} \mathrm{m}^{-2}$; $\mathrm{Rg}=$ global incidental solar radiation with the INMET Climatological Station, $\mathrm{MJ} \mathrm{m}^{-2}$.

The incidental photosynthetically active radiation was estimated to be $45 \%$ of the global solar radiation. This fraction represents the average value of those found for Rio Grande do Sul (PANDOLFO, 1995).

To verify the dependence between carbon accumulation with the PARi, the data were submitted to Pearson's linear correlation "Statistical Analysis System" software (SAS, 2003).

\section{RESULTS}

The global solar radiation flux was on average $2.49 \mathrm{MJ} \mathrm{m}^{-2}$ day $^{-1}$, with a variation of 0.01 to $5.57 \mathrm{MJ}$ $\mathrm{m}^{-2}$ day $^{-1}$ for the intercrop system and an average of $16.60 \mathrm{MJ} \mathrm{m}^{-2}$ day $^{-1}$, with a variation of 0.10 to 37.16 $\mathrm{MJ} \mathrm{m}^{-2} \mathrm{day}^{-1}$ for the monocrop system (Figure 1).

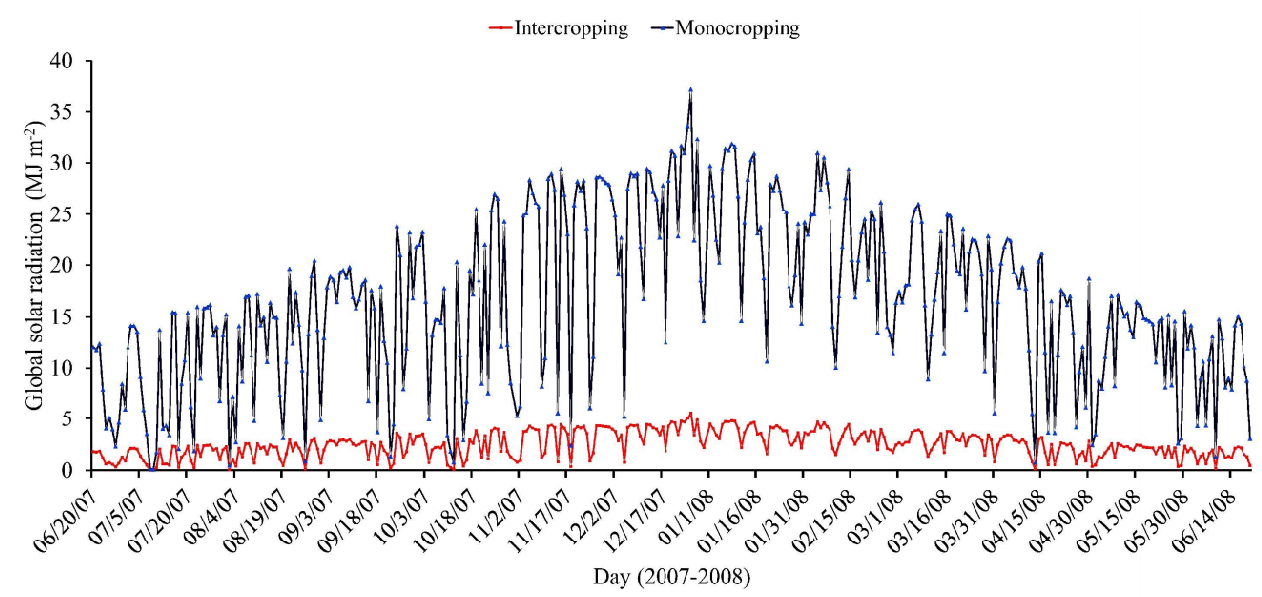

Figure 1 - Global solar radiation incident on the cultivation of Ilex paraguariensis single and estimated global solar radiation incident within the consortium of Ilex paraguariensis and Pinus elliottii, during the period of 06/20/2007 to 06/20/2008 in the city of Frederico Westphalen - RS.

Figura 1 - Radiação solar global incidente no sistema de cultivo de Ilex paraguariensis solteiro e radiação solar global incidente estimada dentro do consórcio de Ilex paraguariensis e Pinus elliottii, durante o período de 20/06/ 2007 à 20/06/2008, no município de Frederico Westphalen - RS.

Revista Árvore, Viçosa-MG, v.40, n.6, p.983-990, 2016 
The results demonstrate that the accumulation in carbon in both culture systems is strongly correlated with the photosynthetically active radiation intercepted accumulated (PARiac), with correlation coefficients equivalent to 0.96 and 0.98 for the intercrop and monocrop system respectively (Figure 2).

The conversion efficiency (åb) in the accumulation of carbon in yerba mate shoots in relation to the amount of accumulated photosynthetically active intercepted solar radiation was of $0.37 \mathrm{~g} \mathrm{MJ}^{-1}$ for the intercrop system and $0.10 \mathrm{~g} \mathrm{MJ}^{-1}$ for the monocrop system (Figure 2).

\section{DISCUSSION}

Although the availability of global solar radiation in the intercrop system (Figure 1) is smaller, due to the interception of the pine plants $(85 \%)$, it can be compensated in part by the increase of the diffuse radiation fraction that is transmitted to the plants, which presents a trait of being multidirectional and better at penetrating the vegetative canopy (BURIOL et al., 1995). In addition, Aikman (1989) found that increased diffuse radiation promoted greater uniformity of radiation within the canopy, causing the lower leaves of the canopy to increase radiation interception and its use.

This trait is responsible for the higher values of åb for carbon accumulation found in the pine cultivation system. This result is corroborated by Sinclair et al. (1992), which demonstrated that in corn and soybean crops, the increase in the diffuse radiation fraction resulted in greater efficiency of the use of radiation by plants.

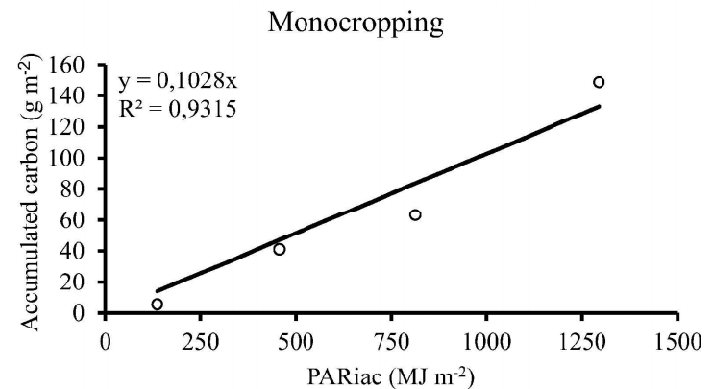

The fact that the conversion efficiency of solar radiation into carbon is higher in the pine-intercrop cultivation reinforces what was reported by Carvalho (2003), who indicated that the yerba mate is considered a shaded plant, accepting shade at any age and tolerating a higher light intensity in adulthood. However, although the use of solar radiation was more efficient in the intercrop system, the accumulation of carbon in the shoot was approximately $35 \%$ larger in the monocrop system. This result can be explained by the higher photosynthetic rate (KASPARY, 1985), since there is a greater availability of global solar radiation, which leads to higher production of dry biomass and consequently carbon. In addition, Taiz and Zeiger (2013) emphasize that the yield of a crop depends on the photosynthetic rates existing in an environment.

In spite of the small amount of work that relates the accumulation of carbon with the incidental photosynthetically active radiation, the results observed here are in agreement with those found by Tollenaar and Bruulsema (1988) that emphasized the existence of a linear relation between phytomass produced and radiant energy intercepted over the course of a large number of species. In healthy plants, which have adequate amounts of water and nutrients available, dry phytomass production is governed by photosynthetically active radiation (PAR) (MONTEITH and MOSS, 1977).

It is important to note that solar radiation is important for plant growth, not only for providing energy for photosynthesis, but also for providing signals that regulate its development through light receptors sensitive to different intensities (ATROCH et al., 2001). Thus,

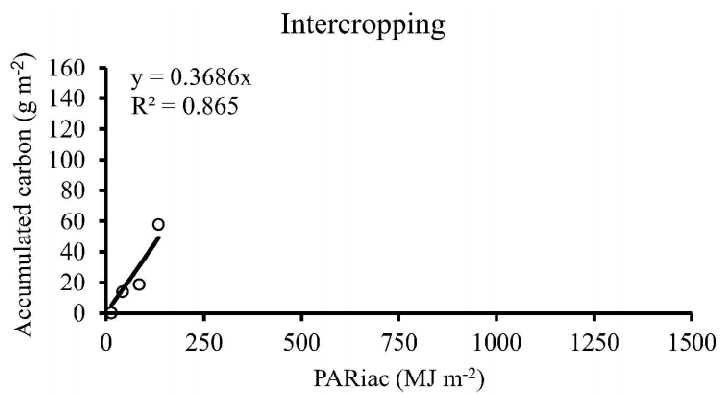

Figure 2 - Relationship between cumulative intercepted photosynthetically active radiation (PARiac) and carbon accumulation in shoots in two cropping systems of Ilex paraguariensis: consortium and single in the city of Frederico Westphalen $-\mathrm{RS}$.

Figura 2 - Relação entre radiação fotossinteticamente ativa interceptada acumulada (RFAiac) e o acúmulo de carbono na parte aérea em dois sistemas de cultivos de Ilex paraguariensis: consórcio e solteiro, no município de Frederico Westphalen - RS. 
the ability of plants to grow in conditions of greater or lesser luminosity depends on their morphological and physiological structures, that is, on adaptive strategies (TILMAN, 1988). In this sense, Coelho et al. (2000) state that levels greater than or equal to $50 \%$ reduction in natural light are sufficient to decrease the phytomass production of yerba mate and consequently the accumulation of carbon. This reinforces that the availability of light ( $15 \%$ for the intercrop system), limits the growth of shaded grasses, a fact that was also verified by Gliessmann (2000).

In field conditions, the conversion efficiency of solar radiation into phytomass was 7.33 to $3.26 \mathrm{~g} \mathrm{MJ}^{-1}$ for eucalyptus, in high and medium density tubes, respectively (CARON et al., 2012), from $2.46 \mathrm{~g} \mathrm{MJ}^{-1}$ for sunflower (BARNI et al., 1995), from $2.60 \mathrm{~g} \mathrm{MJ}^{-1}$ for corn (FRANÇA et al., 1999), from $1.73 \mathrm{~g} \mathrm{MJ}^{-1}$ for rice (STEINMETZ; SIQUEIRA, 2001) and from 0.72 to 1.40 $\mathrm{g} \mathrm{MJ}^{-1}$ for lettuce (CARON et al., 2003).

The higher efficiency for carbon accumulation observed in intercropping, which is linked to the increase of the diffuse radiation in this environment, is caused by the interaction between global solar radiation and the pine canopy. The incident radiation on the surface of yerba mate leaves in intercropping arrives in several ways: directly through the clearings of the canopy and the margins of the settlement, and as diffuse radiation from the reflection of the pine leaves and the surface of the soil, or as radiation transmitted by the leaves of this species. The fact is that there is an increase in the relative contribution of the leaves of the lower yerba mate extracts for phytomass accumulation, and consequently carbon accumulation, as the diffuse fraction increases, and this is higher in a intercropping environment.

Considering the priority of reducing $\mathrm{CO}_{2}$ in the atmosphere and the need to evaluate the potential of forest species to reduce carbon emissions, this study may contribute to direct new research with other forest species in order to determine the amount of fixed carbon.

Since it has been shown that there is a difference in the efficiency of the use of the radiation between the monocropping and intercropping of mate, the results obtained in this work contribute to the management of herbs, mainly for producers that use intercropping, with other forest species, in order to establish appropriate management; so that the plants are partially shaded, thus optimizing the efficiency of the use of radiation by increasing the fraction of diffuse radiation but without compromising productivity.

\section{CONCLUSION}

The highest conversion efficiency ( $\varepsilon b)$ of photosynthetically active solar radiation intercepted in the accumulation of carbon in the shoot of yerba plants is obtained through the intercropping system with Pinus elliottii.

The study of carbon sequestration in agricultural and agroforestry systems (intercrops) by means of estimates that take into account the intercepted photosynthetically active radiation and the efficiency in which it is used by the plants can be applied in several research topics such as: analysis of plant growth, yield prediction, and the potential for carbon sequestration in the region.

\section{REFERENCES}

AIKMAN, D.P. Potential increase in photosynthetic efficiency from the redistribution of solar radiation in a crop. Journal of Experimental Botany, v.40, n.217, p.885864, 1989.

ATROCH, E.M.A; SOARES, Â.M.; ALVARENGA, A.A.; CASTRO, E.M. Crescimento, teor de clorofilas, distribuição de biomassa e características anatômicas de plantas jovens de Bauhinia forticata Link. submetidas a diferentes condições de sombreamento. Ciência e Agrotecnologia, v.25, n.4, p.853-862, 2001.

BALBINO, L.C.; CORDEIRO, L.A.M.; PORFÍRIODA-SILVA, V.; MORAES, A.; MARTÍNEZ, G.B.; ALVARENGA, R.C.; KICHEL, A.N.; FONTANELI, R.S.; SANTOS, H.P.; FRANCHINI, J.C.;

GALERANI, P.R. Evolução tecnológica e arranjos produtivos de sistemas de integração lavoura pecuária floresta no Brasil. Pesquisa

Agropecuária Brasileira, v.46, p.i-xii, 2011. (Prefácio).

BARNI, N.A.; BERLATO, M.A.; BERGAMASCHI, H.; RIBOLDI, J. Rendimento máximo do girassol com base na radiação solar e temperatura. II. Produção de fitomassa e rendimento de grãos. Pesquisa Agropecuária Gaúcha, v. 1, n.2, p.201-216, 1995. 
BENINCASA, M.M.P. Análise de crescimento de plantas; noções básicas. Jaboticabal: FUNEP, 1988. 42p.

BORILLE, W.M.A.; REISSMANN, B.C.; FREITAS, S.J.R. Relação entre compostos fitoquímicos e o nitrogênio em morfotipos de erva-mate (Ilex paraguariensis de St. Hil.). Boletim do Centro de Pesquisas e Processamento de Alimentos, v. 23, n.1, p.183-98, 2005.

BORTOLUZZI, A.L.M.; PASQUALATTO, R.P.R.; GUESSER, G.; CARDOZO JR, E.L.; DONADUZI, C.M.; MITSUI, M. Quantificação de metilxantinas e compostos fenólicos em amostras de erva-mate (Ilex paraguariensis St. Hil.). In: CONGRESSO SUDAMERICANO DE LA YERBA MATE, 4., 2006, Posadas. Anais...Posadas: Actas, 2006. p.143-47.

BROMATOS, S.L. Fitoterapia: vademacum de prescripción. Plantas Medicinales. 3.ed. Barcelona: Masson, 2000. 315p.

BRUNETON, J. Elementos de fitoquímica y de farmacognosia. Paris: Lavoisier, 1993. 544p.

BURIOL, G.A.; STRECK, N.A.; PETRY, C.; SCHNEIDER, F.M. Transmissividade da radiação solar do polietileno de baixa densidade utilizado em estufa. Ciência Rural, v.25, n.1, p.1-4, 1995.

CARON, B.O.; SOUZA, V.Q.D.; TREVISAN, R.; BEHLING, A.; SCHMIDT, D.; BAMBERG, R.; ELOY, E. Eficiência de conversão da radiação fotossinteticamente ativa interceptada em fitomassa de mudas de eucalipto. Revista Árvore, v.36, n.5. p.833-842, 2012.

CARON, B.O.; MEDEIROS, S.L.P.; MANFRON, P.A.; SCHMIDT, D.; BIANCHI, C.; POMMER, S.F. Eficiência de conversão da radiação solar fotossinteticamente ativa interceptada em fitomassa de alface. Revista Brasileira de Agrometeorologia, v.11, n.2, p.261-268, 2003.

CARVALHO, P.E.R. Espécies arbóreas brasileiras. Brasília: Embrapa Informação Tecnológica, 2003. 1039p.

COELHO, G.; RACHWAL, M.; SCHNORRENBERGER, E.; SCHENKEL, E. Efeitos do sombreamento sobre a sobrevivência, morfologia e química da Erva- Mate. In: CONGRESSO SULAMERICANO DA ERVA-MATE, 2., 2000, Encantado, RS. Anais... Encantado: Universidade do Rio Grande do Sul, 2000. v.1. p.396-9.

CUNHA, G.M.; GAMA-RODRIGUES, A.C.; GAMA-RODRIGUES, E.F.; VELLOSO, A.C.X. Biomassa e estoque de carbono e nutrientes em florestas montanas da mata atlântica na região norte do estado do Rio de Janeiro. Revista Brasileira de Ciência do Solo, v.33, p.1175-1185, 2009.

ESMELINDRO, M.C.; TONIAZZO, G.; WACZUK, A.; DARIVA, C.; OLIVEIRA, D.D. Caracterização físico-química da erva mate: Influência das etapas do processamento industrial. Ciência e Tecnologia de Alimentos, v.22, n.2, p.193204, 2002.

FRANÇA, S.; BERGAMASCHI, H.; ROSA, L.M.G. Modelagem do crescimento de milho em função da radiação fotossinteticamente ativa e do acúmulo de graus-dia, com e sem irrigação.

Revista Brasileira de

Agrometeorologia, v.7, n.1, p.59- 66, 1999.

GLIESSMANN, S.R. Agroecologia: processos ecológicos em agricultura sustentável. Porto Alegre: EDURGS/UFRGS, 2000. 653p.

GOMIDE, M.B.; TOURINO, O.V; CARVALHO, D. Comparação entre métodos de determinação de área foliar em cafeeiros Mundo Novo e Catuaí. Ciência Prática, v.1, n.2, p.118-123, 1977.

GOSMANN, G. Saponinas de Ilex paraguariensis de St. Hil. 1989. $108 \mathrm{f}$. Dissertação (Mestrado em Farmácia) Universidade Federal do Rio Grande do Sul, Porto Alegre, 1989.

INSTITUTO BRASIELIRO DE GEOGRAFIA E ESTATISTICA - IBGE. Produção Agrícola Municipal. 2012 [acesso em: 02 ago. 2014]. Disponível em: ftp://ftp.ibge.gov.br/

Producao Agricola/

Producao_Agricola_Municipal_[anual]/2012/ tabelas_pdf/tabela03.pdf.

KASPARY, R. Efeitos de diferentes graus de sombreamento sobre o

Revista Árvore, Viçosa-MG, v.40, n.6, p.983-990, 2016 
desenvolvimento de plantas jovens de erva-mate (Ilex paraguariensis St. Hil.). 1985. 54f. Dissertação (Mestrado em Botânica) Universidade Federal do Rio Grande do Sul, Porto Alegre, 1985.

KASPARY, R.; VALDUGA, E. Benefícios da erva-mate. 2008. [acesso em: 02 jan. 2014].

Disponível em: http://www.erva-mate.com/ benefícios.html.

MALUF, J.R.T. Nova classificação climática do Estado do Rio Grande do Sul. Revista Brasileira de Agrometeorologia, v.8, n.1, p.141-150, 2000 .

MAZUCHOWSKI, J.Z.; MACCARI JUNIOR, A.; SILVA, E.T. Influência de diferentes condições de radiação solar sobre o crescimento morfológico da erva-mate (Ilex paraguariensis A. St. Hil.). In CONGRESO SUL-AMERICANO DA ERVA-MATE, 3., 2003, Chapecó, SC. Anais... Chapecó: EPAGRI, 2003. [CD-ROM]

MONTEITH, J.L.; MOSS, C.J. Climate and the efficiency of crop production en Britain.

Proceedings of the Royal Society of London, v.281, n.980, p.277-294, 1977.

MOSELE, S.H. A governança na cadeia agroindustrial da erva-mate na região do Alto Uruguai Rio Grandense. 2002. 211f. Dissertação (Mestrado em Agronegócios) Universidade Federal do Rio Grande do Sul, Porto Alegre, 2002.

PANDOLFO, C. Parâmetros básicos para uso na modelagem do rendimento de matéria seca de alfafa (Medicago sativa L.). 1995. 128f. Dissertação (Mestrado em Agronomia) - Universidade Federal do Rio Grande do Sul, Porto Alegre, 1995.

POLETTO, I.; MUNIZ, M.F.B.; CECONI, D.E.; MEZZOMO, R.; RODRIGUES, J. Influência da inoculação de Fusarium spp. e níveis de sombreamento no crescimento e desenvolvimento da erva-mate. Ciência Florestal, v.20, n.3, p.513-521, 2010.

RIBEIRO, S.C.; JACOVINE, L.A.G.; SOARES, C.P.B.; MARTINS, S.V.; SOUZA, A.L.D.;
NARDELLI, A.M.B. Quantificação de biomassa e estimativa de estoque de carbono em uma capoeira da Zona da Mata Mineira. Revista Árvore, v.34, p.495-504, 2010.

SAS LEARNING EDITION. Getting started with the SAS learning edition. Cary: 2003. 200p.

SINCLAIR, T.R.; SHIRAIWA, T.; HAMMER, G.L. Variation in crop radiation-use efficiency with increased diffuse radiation. Crop Science, v.32, n.5, p.1281-1284, 1992.

STEINMETZ, S.; SIQUEIRA, O.J.W. Eficiência de conversão em biomassa da radiação solar interceptada nas distintas fases do ciclo de três tipos de planta de arroz irrigado. In: CONGRESSO BRASILEIRO DE AGROMETEOROLOGIA, 3., 2001. Fortaleza, Anais... Fortaleza: Sociedade Brasileira de Agrometeorologia, 2001. v.3. p.691-692.

TAIZ, L.; ZEIGER, E. Fisiologia vegetal. 5.ed Porto Alegre: Artmed, 2013.918p.

TILMAN, D. Plant strategies and the dynamics and structure of plant communities. New Jersey: Princeton University Press, 1988. 362p.

TOLLENAAR, M.; BRUULSEMA, T.W. Efficiency of maize dry matter production during periods of complete leaf area expansion. Agronomy Journal, v.80, p.580-585, 1988.

UNITED NATIONS FRAMEWORK CONVENTION ON CLIMATE CHANGE - UNFCCC. Kyoto Protocol to the United Nations Framework Convention on Climate Change, United Nations. New York: 1997.

VARLET-GRANCHER, C.; GOSSE, G.; CHARTIER, M.; SINOQUET, H.; BONHOMME, R.; ALLIRAND, J.M. Mise au point: rayonnement solaire absorbé ou intercepté par um couvert végétal.

Agronomie, v.9, n.5, p.419-439, 1989.

WEBER, K.S.; BALBINOT, R.; WATZLAWICK, L.F.; SANQUETTA, C.R. Teores de carbono orgânico de seis espécies naturais do ecossistema da Floresta Ombrófila Mista. Revista Ambiência, v.2, n.2, p.167-177, 2006. 